\title{
Pengembangan Bahan Ajar Pergeseran Kesetimbangan Menggunakan Media Visual Untuk Siswa Kelas XI MIA-I SMA Negeri 4 Palangka Raya
}

\author{
Mia Pesie \\ Guru Kimia, SMA Negeri 4, Palangka Raya, Indonesia
}

\begin{abstract}
Abstrak : Hasil belajar siswa pada Kelas XI MIA-I SMA Negeri 4 Palangka Raya, menunjukkan siswa cenderung mengalami kesulitan dalam memahami konsep khususnya. Salah satu penyebab rendahnya hasil belajar adalah ketersediaan buku yang digunakan sebagai sumber belajar siswa. Berdasarkan hasil observasi, sumber belajar kimia dalam Pembelajaran masih memiliki kekurangan, yaitu belum berbasis REACT (relating, experimenting, applying, cooperating, transferring). Oleh karena itu, untuk meningkatkan minat dan motivasi siswa, sebaiknya konsep Pergeseran kesetimbangan didesain dengan lebih baik dalam bentuk pengembangan bahan ajar. Penelitian akan dilakukan pada siswa Kelas XI MIA-I SMA Negeri 4 Palangka Raya Kota Palangka Raya, Kalimantan Tengah. Desain pengembangan bahan ajar dirancang dengan memperhatikan beberapa aspek seperti, aspek pendefinisian, perancangan, pengembangan, dan pengujian pada siswa.
\end{abstract}

\section{Kata kunci: Bahan Ajar, Pergeseran Kesetimbangan}

\section{Pendahuluan}

Kimia merupakan ilmu pengetahuan yang berperan dalam segala aspek kehidupan dijagat raya. Secara lebih spesifik kimia merupakan studi tentang perubahan materi yang disertai perubahan energi. Jadi, ilmu kimia merupakan salah satu bidang ilmu pengetahuan alam yang mempelajari tentang perubahan materi disertai perubahan energi. Strategi adalah suatu kegiatan pembelajaran yang harus dikerjakan guru dan siswa agar tujuan pembelajaran dapat dicapai secara efektif dan efisien. Sedangkan strategi belajar mengajar merupakan cara dan urutan yang ditempuh seorang guru dalam mengajar agar berhasil atau tujuan belajar tercapai (Arifin, dkk: 2000). Kimia adalah suatu ilmu yang mempelajari mengenai komposisi, struktur dan sifat zat atau materi dari skala atom hingga molekul, serta perubahan atau transformasi serta interaksi untuk membentuk materi yang ditemukan dalam kehidupan sehari-hari. Kimia juga mempelajari tentang pemahaman sifat interaksi atau individu dengan tujuan menerapkan pengetahuan (pengertian Kimia dan manfaatnya, 2014).

Menurut Suprihatiningrum, (2013) belajar adalah proses usaha yang dilakukan seseorang untuk memperoleh perubahan tingkah laku yang baru secara keseluruhan, sebagai hasil pengalamannya dalam interaksi dengan lingkungannya. Perubahan tingkah laku itu meliputi perubahan keterampilan, sikap, pengetahuan, pemahaman, danapresiasi. Oleh sebab itu, belajar adalah proses aktif, yaitu proses mereaksi terhadap semua situasi yang ada disekitar individu. Belajar adalah suatu proses yang diarahkan pada suatu tujuan, proses berbuat melalui berbagai pengalaman. Belajar adalah proses melihat, mengamati, memahami sesuatu yang dipelajari. Sehingga sesorang dikatakan belajar apabila terjadi perubahan pada dirinya akibat adanya latihan dan pengalaman melalui interaksi dengan lingkungan. Menurut Dahar (2011) pemahaman konsep diperoleh melalui proses 
belajar kognitif yang Kementrian Pendidikan, (1995) menyatakan bahwa strategi adalah suatu kegiatan pembelajaran yang harus dikerjakan guru dan siswa agar tujuan pembelajaran dapat dicapai secara efektif dan efisien. Sedangkan strategi belajar mengajar merupakan cara dan urutan yang ditempuh seorang guru dalam mengajar agar berhasil atau tujuan belajar tercapai (Arifin, dkk: 2000).

Media visual sebagai media belajar dapat memberikan situasi yang menyenangkan dan tidak kaku dan dapat meningkatkan pemahaman siswa dalam pembelajaran. Media visual ini unik dan menarik perhatian siswa, membuat pelajaran lebih mudah dipahami dan mampu meningkatkan pemahaman siswa dalam pembelajaran kimia. Mata pelajaran kimia di SMA bagi sebagian siswa menganggap sebagai mata pelajaran yang sulit dipahami dan kurang menarik. Hal inilah yang mendasari penulis menggunakan media visual sebagai media pembelajaran Kimia. Media visual dapat digunakan untuk sekolah-sekolah di daerah pendesaan/kecematan yang masih belum lengkap memiliki alat-alat dan bahan-bahan kimia untuk melakukan percobaan. Media visual bisa digunakan untuk menganti percobaan. Berdasarkan latar belakang yang teruraikan di atas, sehingga peneliti mencari alternatif pembelajaran yang diharapkan mampu mengatasi kesulitan-kesulitan yang dialami siswa. Maka peneliti tertarik untuk melakukan penelitiaan dengan judul: "Pengembangan Bahan Ajar Pergeseran Kesetimbangan Menggunakan Media Visual Untuk Siswa Kelas XI MIA-I SMA Negeri 4 Palangka Raya".

Bahan ajar dapat meningkatkan hasil belajar siswa. Istiyono dkk. (2007) memaparkan bahwa penggunaan bahan ajar berupa modul berbasis kontesktual efekif meningkatkan hasil belajar siswa sedangkan, Nentwig et al. (2007) menjelaskan pada pengembangan pembelajaran kontekstual di Jerman yang dikenal dengan istilah Chemie im Kontext terbukti aktif dalam meningkatkan kualitas pembelajaran kimia mulai dari proses sampai hasilnya. Berdasarkan fakta empiris, bahan ajar dapat meningkatkan hasil belajar siswa pada materi kimia sehingga perlu dikembangkan khususnya pada materi pergeseran kesetimbangan.

\section{Metode}

\section{A. Model Penelitian dan Pengembangan}

Model penelitian pengembangan bahan ajar materi Pergeseran Kesetimbangan menggunakan model 4-D Thiagarajan et al. (1974). Tahap penyebarluasan tidak dilakukan karena disesuaikan dengan tujuan penelitian.

\section{B. Prosedur Penelitian dan Pengembangan}

Penelitian akan dilakukan pada Siswa Kelas XI MIA-I SMA Negeri 4 Palangka Raya Tahun Ajaran 2017/2018. Desain pengembangan dirancang dengan memperhatikan beberapa aspek seperti, aspek pendefinisian, perancangan, pengembangan, dan pengujian pada siswa. Rancangan model penelitian dan pengembangan disajikan pada Gambar 6. 


\section{Tahap Pendefinisian}

\section{a. Analisis Masalah}

Tujuan identifikasi masalah yaitu untuk mengetahui latar belakang yang terjadi dalam ruang lingkup penelitian. Tahap identifikasi masalah dilakukan sebagai berikut.

1. Analisis nilai UTS dan UAS siswa pada mata pelajaran Kimia selama tiga tahun terakhir (2013, 2014, dan 2015).

2. Analisis kurikulum Kimia di sekolah SMA Negeri 4 Palangka Raya.

3. Wawancara pada siswa kelas XI yang telah menempuh mata pelajaran Kimia kelas XI.

4. Identifikasi masalah yang ditinjau dari buku ajar yang digunakan sebagai penunjang pengajaran.

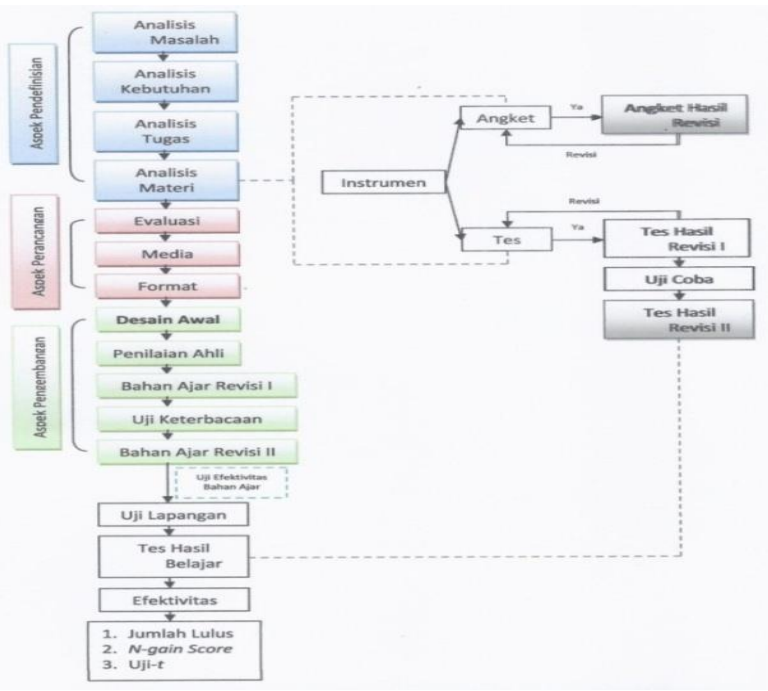

\section{Gambar 1. Tahapan Prosedur Penelitian dan Pengembangan Bahan Ajar}

\section{b. Analisis Kebutuhan}

Analisis kebutuhan bertujuan untuk menyesuaikan psikologis siswa terhadap kompetensi yang ditetapkan dalam tujuan pembelajaran. Langkah analisis kebutuhan yaitu:

1. Observasi sampel yang memiliki masalah.

2. Analisis karakteristik siswa.

3. Desain pembelajaran.

4. Observasi sumber belajar.

\section{c. Analisis Tugas}

Analisis tugas mengkaji keterampilan utama yang dimiliki siswa setelah mengikuti proses pembelajaran.

\section{d. Analisis Materi}

Analisis dilakukan untuk mengkaji materi sehingga ruang lingkup dan tujuan pembelajaran dapat diketahui. Cakupan analisis meliputi Kompetensi Inti, 
Kompetensi Dasar (KD), materi pokok, dan indikator. Langkah yang dilakukan pada tahap analisis adalah:

1) Merangkum relevansi karakteristik dan cakupan materi sebagai dasar mendesain bahan ajar.

2) Mempelajari karakteristik materi pergeseran kesetimbangan mata pelajaran Kimia.

3) Mengkaji Kompetensi Inti, Kompetensi Dasar, materi pokok, dan indikator.

4) Menganalisis karakteristik dalam materi Pergeseran Kesetimbangan.

\section{Tahap Perancangan}

a. Evaluasi

Angket dan tes merupakan bentuk evaluasi yang akan dirancang pada tahap ini. Angket disusun untuk mengetahui kelayakan dan keterbacaan bahan ajar sedangkan tes disusun untuk mengetahui efektivitas bahan ajar.

Pemilihan media merupakan langkah untuk menentukan media yang sesuai dengan kondisi siswa, tujuan, dan cakupan materi.

\section{b. Format}

Pemilihan format merujuk pada bentuk fisik produk yang akan dikembangkan seperti jenis, gaya, tampilan warna, dan ukuran tulisan. Format bahan ajar akan dirancang berbahasa Indonesia, portrait, berwarna, dan kertas A4. Format tulisan ukuran 12 tipe Times New Roman, namun pada bagian bahan ajar diberikan beberapa tipe huruf agar membuat tampilan menjadi menarik.

\section{c. Desain Awal}

Desain produk yang dikembangkan dalam bentuk bahan ajar untuk siswa.

\section{Tahap Pengembangan}

Tahap pengembangan meliputi: (a) penyusunan instrumen penelitian, (b) pemilihan validator, (c) desain revisi I, (d) uji keterbacaan perorangan, (e) desain revisi II.

\section{Uji Lapangan}

Uji lapangan meliputi uji coba penggunaan bahan ajar hasil pengembangan dalam pembelajaran dengan materi Pergeseran Kesetimbangan yang dilaksanakan pada siswa Kelas XI MIA-I SMA Negeri 4 Palangka Raya semester genap Tahun Ajaran 2017/2018.

\section{Tes Hasil Belajar}

Pengumpulan data tes hasil belajar dilakukan setelah kegiatan pembelajaran menggunakan bahan ajar hasil pengembangan. Siswa diberikan soal 
dalam bentuk essay berjumlah 4 soal, tanpa melihat bahan ajar dengan alokasi waktu selama 30 menit.

Persentase pemahaman konsep siswa pada setiap indikator dapat ditelusuri dengan menganalisis pola jawaban siswa pada pretes dan postes. Peningkatan pemahaman konsep dihitung menggunakan rumus Normalitas gain. Gain adalah selisih nilai postes dan pretes, gain menunjukkan peningkatan pemahaman siswa setelah pembelajaran dilakukan. Dimana untuk menghitung nilai gain digunakan rumus berikut :

$$
\mathrm{g}=\frac{\mathrm{s}_{\text {postes }}-\mathrm{s}_{\text {pretes }}}{\text { skor maksimum }-\mathrm{s}_{\text {pretes }}}
$$

Persentase peningkatan setiap indikator digolongkan ke dalam kategori sesuai Tabel 3.1.

Tabel 1. Kategori Peningkatan Pemahaman

\begin{tabular}{cc}
\hline Besar Persentase & Kategori \\
\hline $\mathrm{g} \geq 0,7$ & Tinggi \\
$0,7>\mathrm{g} \geq 0,3$ & Sedang \\
$\mathrm{g}<0,3$ & Rendah \\
\hline
\end{tabular}

\section{Hasil Dan Pembahasan}

Produk hasil pengembangan berupa bahan ajar yang disusun berbasis kontekstual. Materi yang dipilih sebagai konsep pembelajaran untuk pengembangan produk adalah Pergeseran Kesetimbangan mata pelajaran Kimia. Hasil pengembangan produk terdiri dari Bahan Ajar dalam bentuk uraian materi dan LKS. Bab IV menjelaskan tentang beberapa bagian seperti : (A) deskripsi hasil pengembangan ; (b) penyajian data uji coba dan (c) analisis data.

\section{A. Deskripsi Hasil Pengembangan}

Produk akhir dari penelitian pengembangan adalah Desain Revisi II yang terdiri dari Bahan Ajar dalam bentuk uraian materi dan LKS. Produk yang dihasilkan berupa Bahan Ajar Pergeseran Kesetimbangan berbasis kontekstual untuk Mata Pelajaran Kimia.

1. Bahan Ajar Guru

Bahan ajar petunjuk Guru adalah Produk hasil pengembangan yang bertujuan untuk pedoman Guru dalam menggunakan bahan ajar Pergeseran

Kesetimbangan berbasis kontekstual.

a. Cover Bahan Ajar dirancang dengan menggambarkan secara umum tentang materi yang akan dibahas per bagiannya. Setiap bagian berisi Judul Bagian, Tujuan Pembelajaran dan Selingan Motivasi. Selain itu, latar menggunakan gambar yang berhubungan dengan materi yang akan dipelajari.

b. Kata Pengantar Guru diawali dengan kata pengantar. Bagian ini mendeskripsikan secara garis besar mengenai bahan ajar yang telah dikembangkan. 
c. Daftar Isi diberikan untuk mempermudah dosen mencari langsung bagian yang diinginkan pada bahan ajar.

d. Deskripsi Penggunaan Bahan Ajar memaparkan secara garis besar mengenai bagian-bagian penting yang disajikan dalam bahan ajar. Hal ini bertujuan untuk memberikan informasi kepada Guru tentang isi bahan ajar.

e. Prasyarat disajikan pada bahan ajar petunjuk Guru bertujuan untuk memberikan informasi kepada Guru mengenai prasyarat yang harus dipahami siswa sebelum mempelajari materi Pergeseran Kesetimbangan.

f. Deskripsi Pendekatan Kontekstual menjelaskan definisi pendekatan kontekstual. Lima elemen karakteristik pendekatan konstekstual dijelaskan satu per satu. Adapun kelima elemen tersebut yaitu relating, experimenting, applying, cooperating dan transferring.

g. Petunjuk untuk Guru dalam menggunakan bahan ajar disusun dalam bagian petunjuk untuk Guru. Petunjuk disusun sebagai acuan Guru dalam membimbing siswa.

h. Silabus Konsep Pergeseran Kesetimbangan terdiri dari (1) Identitas penggunaan silabus seperti nama Sekolah, mata pelajaran, materi pokok, semester, standar kompetensi, pertemuan ke-, dan alokasi waktu ; (2) Kompetensi Isi ; (3) Kompetensi Dasar ; (4) Materi Pokok ; (5) Indikator dan (6) Kegiatan Pembelajaran berdasarkan Pendekatan Kontekstual. Guru menggunakan silabus sebagai pedoman mengajarkan materi Pergeseran Kesetimbangan kepada siswa.

i. Rencana Pelaksanaan Pembelajaran memuat rincian mengenai (1) identitas pengguna terdiri dari mata pelajaran, materi pokok, semester, jumlah pertemuan dan alokasi waktu ; (2) Kompetensi Inti ; (3) Kompetensi Dasar ; (4) Indikator ; (5) Tujuan Pembelajaran ; (6) Pendekatan dan Metode Pembelajaran ; (7) Rencana Pembelajaran ; (8) Penilaian pada Pembelajaran Kontekstual.

j. Kegiatan Pembelajaran Berbasis Kontekstual pada Bahan Ajar meliputi beberapa elemen karakteristik seperti relalting, experimentin, applying, cooperating dan transferring. Masing-masing elemen karakteristik disesuaikan dengan karakteristik materi yang dibahas. Penjelasan lebih rinci mengenai elemen karakteristik pendekatan kontekstual pada bagian bahan ajar dapat dilihat pada sub bagian Rencana Pelaksanaan Pembelajaran pada Bahan ajar Petunjuk Guru.

1) Relating merupakan proses belajar dengan mengaitkan bekal pengetahuan pada diri siswa pada konteks pengalaman hidup sebelumnya. Bahan ajar ini telah mengembangkan bagian relating pada halaman setelah cover Bahan Ajar. Artikel berkaitan dengan materi yang akan dipelajari. Bagian ini disajikan secara menarik dengan menambahkan gambar-gambar dan sumbersumber artikel. 


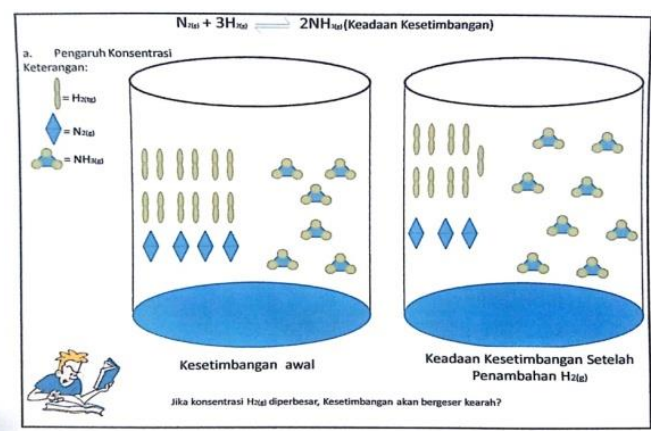

\section{Gambar 2. Bagian Relating pada Bahan Ajar Pergeseran Kesetimbangan}

Gambar 4.1 merupakan salah satu contoh relating pada bagian materi Pergeseran Kesetimbangan. Tahap relating pada uraian materi Pengaruh Konsentrasi. Setelah membaca artikel maka siswa akan mengetahui bahwa pengaruh konsentrasi pada saat kesetimbangan awal dan keadaan kesetimbangan setelah penambahan $\mathrm{H}_{2}$. Sajian artikel diharapkan mampu membangkitkan motivasi siswa untuk mengetahui lebih lanjut tentang arah Pergeseran Kesetimbangan.

Sumber-sumber artikel diberikan agar mempermudah siswa untuk mengakses lebih lanjut. Selain itu, pertanyaan-pertanyaan ditampilkan secara eksplisit untuk lebih membangkitkan motivasi siswa dalam mempelajari Pergeseran Kesetimbangan.

2) Experimenting Pengetahuan atau konsep yang diperoleh siswa berdasarkan data-data empiris merupakan karakteristik experimenting pada pendekatan kontestual. Beberapa bagian pada bahan ajar didesain dengan menyajikan data-data dalam bentuk Gambar. Gambar disajikan agar siswa mudah menganalisis data untuk menemukan konsep. Bentuk experimenting dalam bahan ajar disajikan pada LKS.

Siswa diminta untuk menganalisis Gambar-gambar dalam bahan ajar tentang Pergeseran Kesetimbangan setiap adanya pengaruh konsentrasi. Pertanyaanpertanyaan yang diberikan sebagai acuan dasar untuk menarik kesimpulan. Kesimpulannya yaitu jika konsentrasi diperbesar maka kesetimbangan akan bergeser ke arah kanan. 


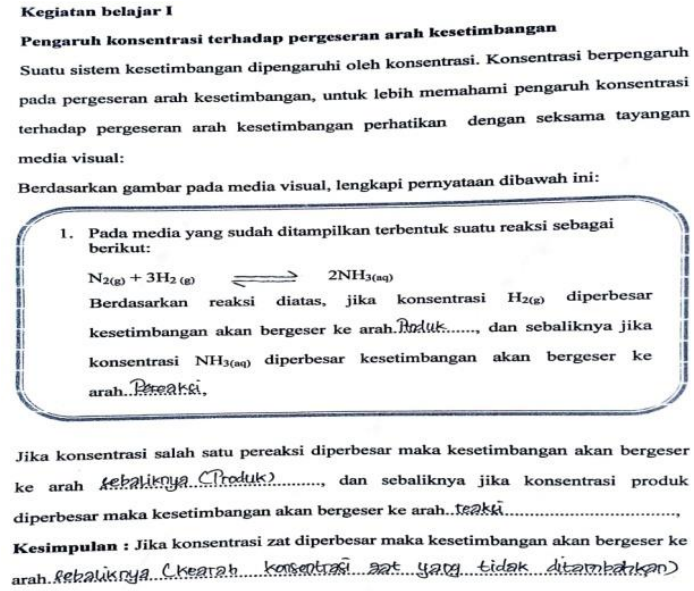

\section{Gambar 3. Bagian Experimenting Bahan Ajar Pergeseran Kesetimbangan}

3) Applying menekankan pada penerapan fakta, konsep, prinsip, dan prosedur yang dipelajari dalam situasi konteks lain. Seperti halnya siswa yang telah memiliki konsep terdahulu sehingga dapat digunakan sebagai dasar untuk mempelajari materi baru. Karakteristik applying dirancang dengan menyajikan bacaan berupa artikel maupun ringkasan materi terkait dengan materi yang dipelajari. Salah satu contoh bagian applying pada bahan ajar disajikan pada gambar bacaan bahan ajar merupakan salah satu kegunaan mempelajari Pergeseran Kesetimbangan. Dengan mempelajari pengaruh konsentrasi, tekanan, volume dan suhu.

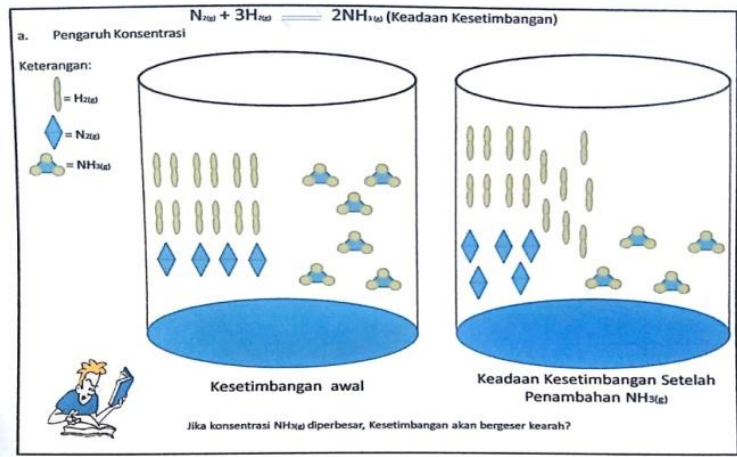

\section{Gambar 4. Bagian Applying pada Pergeseran Kesetimbangan}

Pertanyaan dalam LKS dapat dijawab berdasarkan langkah-langkah penyelesaian untuk setiap Pergeseran Kesetimbangan. Pertanyaan tentang pengaruh konsentrasi. Pengetahuan yang harus dimiliki siswa untuk menjawab soal-soal tersebut adalah dapat menghubungkan antara konsentrasi awal dan setelah penambahan $\mathrm{NH}_{3}$.

4) Cooperating Pembelajaran menggunakan pendekatan kontekstual meliputi salah satunya adalah cooperating. Cooperating atau kerjasama berfungsi untuk mendorong interaksi siswa dengan Guru atau siswa dengan siswa pada kegiatan belajar mengajar. Perintah pembentukan kelompok tidak disajikan 
secara eksplisit melainkan dipandu oleh guru yang berperan sebagai fasilitator. Guru mengorganisasikan siswa dalam kelompok heterogen untuk mendiskusikan kegiatan dalam bahan ajar tentang pergeseran kesetimbangan pada setiap pengaruh kesetimbangan. Interaksi positif sangat diperlukan dalam mengerjakan kegiatan dalam bahan ajar.

5) Transferring Pembelajaran kontekstual menekankan pada kemampuan siswa mentransfer pengetahuan, keterampilan, dan sikap yang telah dimiliki dalam memecahkan masalah baru. Transferring dirancang berbentuk soal latihan. Soal latihan terdiri dari soal essay. Soal essay dirancang dalam bentuk gambar dan isian yang wajib diisi siswa untuk dapat menentukan kecenderungan arah pergeseran kesetimbangann melalui pengaruh konsentrasi, tekanan, volume dan suhu.

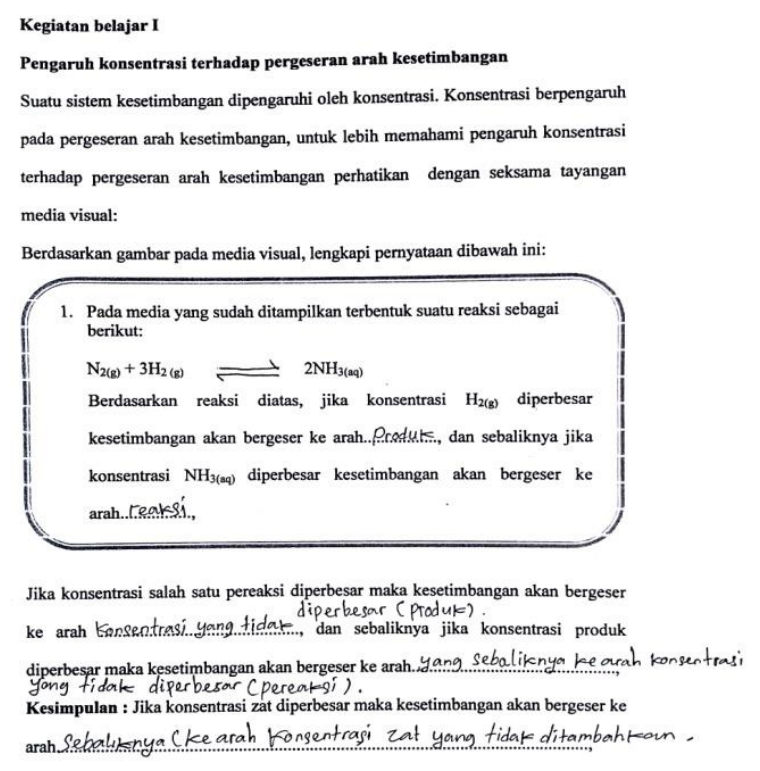

\section{Gambar 5. Penerapan Cooperating Pergeseran Kesetimbangan}

k. Kunci Jawaban bahan ajar yang berisi pembahasan untuk semua pertanyaan yang terdapat dalam bahan ajar.

1. Daftar Pustaka merupakan rujukan yang digunakan dalam penyusunan bahan ajar. Berisi referensi-referensi yang digunakan untuk pengembangan produk.

\section{Penyajian Data Validasi, Uji Keterbacaan Perorangan, dan Revisi Produk}

1. Data Validasi

Validasi dilakukan pada instrumen soal, angket uji keterbacaan perorangan, angket rubrik penilaian bahan ajar, pergeseran kesetimbangan. Instrumen angket, rubrik, bahan ajar, dan bahan ajar petunjuk guru divalidasi oleh tiga validator. Tabel 2 merupakan data kuantitatif dari hasil validasi ahli merupakan data kualitatif berisi saran dan perbaikan. Saran dan perbaikan yang 
diberikan oleh validator menjadi acuan pertimbangan langkah selanjutnya. Dengan demikian, produk hasil validasi ahli merupakan desain revisi I.

Tabel 2. Validasi Ahli untuk Produk Pengembangan dan Angket

\begin{tabular}{lcc}
\hline \multicolumn{1}{c}{ Aspek yang Dinilai } & Persentase rata-rata (\%) & Kategori \\
\hline Bahan Ajar Guru & 91,8 & Layak \\
Uji Keterbacaan Perorangan & 92,9 & Layak \\
\hline
\end{tabular}

Tabel 2 memaparkan bahwa hasil validasi ahli memberikan skor rata-rata kelayakan Bahan ajar Guru dan Uji Keterbacaan Perorangan dengan kategori layak masing-masing 91,8 dan 92,9\%. Oleh karena itu, instrumen dikategorikan layak untuk digunakan ke tahap uji keterbacaan perorangan.

\section{Tabel 3. Saran Perbaikan Ahli}

\begin{tabular}{|c|c|}
\hline Validator & Saran Perbaikan \\
\hline \multirow{2}{*}{1} & - Pada bagian Daftar Isi Bahan Ajar sebaiknya lebih rinci lagi. \\
\hline & - Pada materi Prasyarat belum tercantum atau belum ada. \\
\hline \multirow[b]{2}{*}{2} & - Pada bagian Daftar Isi sesuaikan dengan isi bahan ajar. \\
\hline & $\begin{array}{l}\text { - Pada Uraian Topik perlu ditambahkan materi pergeseran kesetimbangan untuk } \\
\text { lebih memperjelas materi. }\end{array}$ \\
\hline \multirow{3}{*}{3} & $\begin{array}{l}\text { - Pada Cover Bahan Ajar Dosen warna kurang menarik (gunakan warna yang lebih } \\
\text { cerah) }\end{array}$ \\
\hline & $\begin{array}{l}\text { - Pada bagian Peta Konsep halaman IV (daftar isi) tidak atau belum sesuai dengan } \\
\text { halaman Peta Konsep }\end{array}$ \\
\hline & - Perlu diperhatikan penulisan ketikan karena masih banyak salah ketik \\
\hline \multirow{2}{*}{4} & - Perlu bagian Gambar 3 Keterbacaan tulisan kurang jelas. \\
\hline & - Perlu bagian Gambar 4 perlu diperjelas. \\
\hline
\end{tabular}

\section{Uji Keterbacaan Perorangan}

Setelah melalui tahap uji coba soal maka dilakukan pengelompokan. Siswa diklasifikasikan menjadi tiga peringkat yaitu peringkat atas, sedang, dan bawah.Tiga orang dari masing-masing peringkat diambil untuk melakukan uji keterbacaan perorangan. Total siswa yaitu sembilan orang.

Produk pengembangan yang telah melewati proses validasi kemudian diuji keterbacaannya secara empiris. Produk yang diuji adalah bahan ajar untuk siswa. Siswa diberikan waktu selama dua hari untuk memberikan penilaian terhadap bahan ajar revisi I. Hasil uji keterbacaan perorangan disajikan pada Tabel 3, sedangkan pada Tabel 4 diberikan data kualitatif berdasarkan penilaian siswa. Persentase rata-rata bahan ajar dengan kategori layak diperoleh 92,9\%.

Tabel 4. Saran Perbaikan dan Komentar Uji Perorangan

\begin{tabular}{|c|c|c|}
\hline Siswa & Saran Perbaikan & Komentar \\
\hline 1 (Ali) & $\begin{array}{l}\text { - Beberapa bagian pada materi } \\
\text { bahan ajar kalimatnya agak rancu } \\
\text { juga penulisan kata sambung } \\
\text { yang terbalik, mohon } \\
\text { diperhatikan kembali. }\end{array}$ & $\begin{array}{l}\text { - Berdasarkan hasil review yang telah } \\
\text { dilakukan secara keseluruhan bahan ajar ini } \\
\text { sudah cukup memadai, baik dan menarik } \\
\text { digunakan sebagai panduan belajar mengenai } \\
\text { materi pergeseran kesetimbangan. }\end{array}$ \\
\hline 2 (PA) & $\begin{array}{l}\text { - Tulisan pada gambar sebagian } \\
\text { tidak jelas bisa dicek lagi. }\end{array}$ & $\begin{array}{l}\text { - Bahan Ajar sudah sangat menarik karena } \\
\text { disajikan gambar-gambar, penuh warna, dan } \\
\text { bahasa yang digunakan sangat mudah }\end{array}$ \\
\hline
\end{tabular}




\begin{tabular}{|c|c|c|}
\hline Siswa & Saran Perbaikan & Komentar \\
\hline 3 (VA) & $\begin{array}{l}\text { - Sebaiknya ditambahkan gambar- } \\
\text { gambar agar mempermudah } \\
\text { siswa untuk membacanya. }\end{array}$ & $\begin{array}{l}\text { dipahami. } \\
\text { - Isi bahan ajar cukup lengkap dan mudah } \\
\text { dimengerti serta tampilan bahan ajar sangat } \\
\text { menarik. }\end{array}$ \\
\hline $4(\mathrm{DO})$ & $\begin{array}{l}\text { - Gambar sedikit kurang jelas pada } \\
\text { bagian "Deskripsi Penggunaan } \\
\text { Bahan Ajar" }\end{array}$ & $\begin{array}{l}\text { - Bahan Ajar sudah sangat bagus, jelas dan } \\
\text { mudah dipahami. }\end{array}$ \\
\hline $5(\mathrm{UN})$ & $\begin{array}{l}\text { - Perhatikan penulisan, masih } \\
\text { terdapat salah ketik dan } \\
\text { sebaiknya dibaca kembali setiap } \\
\text { paragraph agar tidak terlalu } \\
\text { panjang. }\end{array}$ & $\begin{array}{l}\text { - Secara umum bahan ajar ini sudah bagus } \\
\text { karena jarang sekali diulas secara detail } \\
\text { tentang pergeseran kesetimbangan. } \\
\text { Pertanyaan-pertanyaan yang disajikan sangat } \\
\text { membantu siswa untuk memperdalam materi } \\
\text { pergeseran kesetimbangan. Bahan ajar } \\
\text { ditampilkan dengan warna dan gambar yang } \\
\text { sangat menarik, serta penggunaan kata yang } \\
\text { tidak rumit untuk dipahami. }\end{array}$ \\
\hline $\begin{array}{l}6 \\
(\mathrm{WEL})\end{array}$ & $\begin{array}{l}\text { - Perhatikan penulisan, masih } \\
\text { terdapat banyak salah ketik. }\end{array}$ & $\begin{array}{l}\text { - Bahan ajar sangat bagus karena menampilkan } \\
\text { gambar-gambar yang berkaitan dengan } \\
\text { materi, tujuan pembelajaran diberikan secara } \\
\text { eksplisit, serta mencantumkan artikel-artikel } \\
\text { yang berkaitan sehingga menjadi sumber } \\
\text { tambahan referensi bacaan. }\end{array}$ \\
\hline $\begin{array}{l}7 \\
(\mathrm{MO})\end{array}$ & $\begin{array}{l}\text { - Kata pengantarnya sudah baik } \\
\text { namun tulisan hurufnya ada yang } \\
\text { ketinggalan. } \\
\text { - Perbaiki penulisannya, masih } \\
\text { terdapat salah ketik. }\end{array}$ & $\begin{array}{l}\text { - Secara umum bahan ajarnya sangat menarik } \\
\text { untuk menambah wawasan dan pengetahuan } \\
\text { mengenai pergeseran kesetimbangan. }\end{array}$ \\
\hline 8 (MS) & $\begin{array}{l}\text { - Terdapat salah ketik pada } \\
\text { kalimatnya, mohon diperhatikan } \\
\text { kembali. }\end{array}$ & $\begin{array}{l}\text { - Adanya pertanyaan, uji diri, kegiatan, } \\
\text { tahukah kamu?, catatan pinggir ingatlah, } \\
\text { bacaan, serta kotak biru dapat membantu } \\
\text { dalam memahami materi pergeseran } \\
\text { kesetimbangan. Selain itu, bagian bacaan dan } \\
\text { informasi khususnya dapat memberi } \\
\text { kesadaran pada siswa bahwa lebih mudah } \\
\text { mempelajari pergeseran kesetimbangan. } \\
\text { - Secara umum bahan ajar ini sangat baik } \\
\text { digunakan untuk mempelajari pergeseran } \\
\text { kesetimbangan. }\end{array}$ \\
\hline $9(\mathrm{OP})$ & $\begin{array}{l}\text { - Pada halaman } 30-31 \text { bagian } 3.4 .5 \\
\text { kelebihan, seharusnya menjadi } \\
\text { 3.1.11. mohon di cek. }\end{array}$ & $\begin{array}{l}\text { - Secara keseluruhan sudah bagus, penjelasan } \\
\text { mudah dipahami dan bahan ajarnya menarik } \\
\text { dari segi tampilan. Hanya saja ketikan sedikit } \\
\text { kurang rapi. }\end{array}$ \\
\hline
\end{tabular}

3. Hasil Revisi dan Perbaikan dilakukan setelah melewati proses validasi ahli dan uji keterbacaan perorangan.

a. Desain Revisi I sebagai pedoman pertimbangan revisi bahan ajar mengacu pada saran perbaikan oleh empat orang validator yang disajikan pada Tabel 3.

1) Revisi Berdasarkan Saran Perbaikan dari Validator 1

a) Saran Perbaikan:

Pada bagian Daftar Isi Bahan Ajar sebaiknya lebih rinci lagi.

Revisi:

Daftar isi bahan ajar sudah dibuat lebih rinci. 
b) Saran Perbaikan:

Pada materi Prasyarat belum tercantum atau belum ada.

Revisi:

Materi Prasyarat sudah dicantumkan.

2) Revisi Berdasarkan Saran Perbaikan dari Validator 2

a) Saran Perbaikan:

Pada bagian Daftar Isi sesuaikan dengan isi bahan ajar.

Revisi:

Bagian Daftar Isi sudah disesuaikan dengan isi bahan ajar.

b) Saran Perbaikan:

Pada Uraian Topik perlu ditambahkan materi pergeseran kesetimbangan untuk lebih memperjelas materi.

Revisi:

Pada Uraian Topik sudah ditambahkan materi pergeseran kesetimbangan.

3) Revisi Berdasarkan Saran Perbaikan dari Validator 3

a) Saran Perbaikan:

Pada Cover Bahan Ajar untuk siswa warna kurang menarik (gunakan warna yang lebih cerah)

Revisi:

Cover Bahan Ajar Dosen sudah dimodifikasi menjadi lebih baik.

b) Saran Perbaikan:

Pada bagian Peta Konsep halaman IV (daftar isi) tidak atau belum sesuai dengan halaman Peta Konsep

Revisi:

Peta konsep halaman IV (daftar isi) sudah sesuai dengan halaman.

c) Saran Perbaikan:

Perlu diperhatikan penulisan ketikan karena masih banyak salah ketik Revisi: penulisan ketikan sudah diperbaiki.

4) Revisi Berdasarkan Saran Perbaikan dari Validator 4

a) Saran Perbaikan:

Perlu bagian Gambar 3 Keterbacaan tulisan kurang jelas.

Revisi:

Gambar 3 keterbacaannya sudah jelas.

b) Saran Perbaikan:

Perlu bagian Gambar 4 perlu diperjelas.

Revisi:

Gambar 4 sudah diperjelas.

b. Desain Revisi II

Desain revisi II merupakan langkah setelah Desain Revisi I. Hasil perbaikan meliputi hasil dari uji keterbacaan perorangan. Rekapitulasi saran 
perbaikan disajikan pada Tabel 4. Revisi berdasarkan saran perbaikan Tabel 5 mengahasilkan Desain Revisi II.

1) Revisi Berdasarkan Saran Perbaikan dari Siswa 1, 3, 5, 6, 7, 8

Saran Perbaikan:

Secara umum siswa meminta untuk melakukan perbaikan kesalahan ketikan pada penulisan bahan ajar.

Revisi:

Penulisan ketikan telah dikaji ulang dan direvisi.

2) Revisi Berdasarkan Saran Perbaikan dari siswa 3

Saran Perbaikan:

Sebaiknya ditambahkan bentuk lain agar mempermudah siswa untuk membacanya.

Revisi:

Telah ditambahkan bentuk lain untuk setiap unsur.

3) Revisi Berdasarkan Saran Perbaikan dari Siswa 4

Saran Perbaikan:

Gambar sedikit kurang jelas pada bagian "Deskripsi Penggunaan Bahan Ajar"

Revisi:

Gambar telah diperjelas sesuai saran perbaikan.

4) Revisi Berdasarkan Saran Perbaikan dari siswa 9

Saran Perbaikan:

Pada halaman 30-31 bagian 3.4.5 kelebihan, seharusnya menjadi 3.1.11. mohon di cek.

Revisi:

Halaman tersebut sudah direvisi.

\section{B. Uji Efektivitas}

Uji lapangan dilakukan melalui tiga tahap yaitu pemberian pretes, pelaksanaan pembelajaran menggunakan bahan ajar dan postes.

1) Pelaksanaan Uji Efektivitas

a) Pretes dan Postes

Pretes dilakukan untuk mengetahui pengetahuan awal siswa tentang materi pergeseran kesetimbangan. Pretes dilaksanakan pada tanggal 13 September 2017. Siswa yang mengikuti pretes sebanyak 47 orang. Gambar 4.2 adalah dokumentasi tahap pelaksanaan pretes. Soal pretes dibuat dalam dua format yaitu kode A dan B dengan nomor urut yang diacak tetapi soalnya sama. Tabel 4.5 disajikan data rekapitulasi hasil pretes dan postes. 
Tabel 5. Persentase Lulus pada Pretes dan Postes

\begin{tabular}{ccc}
\hline Uji & Lulus (\%) & Nilai Rata-rata \\
\hline \multicolumn{1}{c}{ Pretes } & 8,5 & 36,60 \\
Postes & 93,6 & 70,70 \\
\hline Keterangan: & & \\
Skor minimal lulus & $=55,5$ & \\
Rentang skor & $=0-100$ &
\end{tabular}

Postes dilaksanakan setelah pelaksanaan proses belajar mengajar menggunakan Bahan Ajar pergeseran kesetimbangan. Postes dilaksanakan pada tanggal 13 September 2017 dan diikuti oleh 47 siswa. Soal postes memiliki soal yang sama dengan soal pretes namun nomor soal diacak. Rekapitulasi hasil postes disajikan pada Tabel 4.5 .

b) Penggunaan Bahan Ajar pada Proses Pembelajaran

Siswa yang telah mengikuti pretes selanjutnya diberi bahan ajar. Bahan ajar dibagikan pada tanggal 13 September 2017. Hal ini bertujuan untuk mengetahui efektivitas penggunaan bahan ajar setelah digunakan oleh siswa. Siswa yang terlibat sebanyak 47 orang. Gambar 4.4 dan 4.5 merupakan dokumentasi pelaksanaan penggunaan bahan ajar pada pertemuan rutin. Efektivitas bahan ajar diukur dari persentase jumlah skor dan n-gain score. Penerapan pelaksanaan pembelajaran menggunakan pendekatan kontekstual. Total pertemuan sebanyak lima kali tatap muka. Selama proses pembelajaran berlangsung peneliti dibantu oleh tiga orang pengamat. Pengamat bertugas menilai proses belajar mengajar setiap pertemuan menggunakan rubrik. Gambar 4.6 adalah beberapa pengamat yang sedang menilai proses belajar mengajar. Pengamat juga bertugas menilai aktivitas dan sikap siswa dalam pembelajaran. Lembar penilaian aktivitas dan sikap siswa. Berdasarkan data rata-rata skor penilaian total adalah 3,7. Skor ini menunjukkan bahwa guru telah melaksanakan pembelajaran menggunakan bahan ajar pergeseran kesetimbangan dengan baik. Tabel 4.6 memaparkan tentang persentase masing-masing penilaian aktivitas siswa dengan kategori baik dalam aspek menganalisis data berupa tabel, skema, dan bacaan sebesar 53,2\%. Persentase rata-rata pada aspek menjawab pertanyaan pada uji diri, pertanyaan, kegiatan, dan kotak biru sebesar 42,6\%. Kemampuan siswa menemukan konsep yang diperoleh berdasarkan analisis data yaitu 46,8\%. Mengajukan pertanyaan antar siswa atau dengan guru sebesar 51,1\%. Sedangkan mempresentasikan hasil diskusi kelompok yaitu 46,8\%.

Penilaian sikap siswa dengan kategori baik selama proses pembelajaran disajikan pada Tabel 4.7. Data menunjukkan bahwa sikap kedisiplinan, tanggung jawab, toleransi, kerjasama, dan perhatian berturut-turut sebesar 68,1\%; 40,4\%, 51,1\%; 47,9\%; dan 40,9\%. Berdasarkan hasil penilaian aktivitas dan sikap siswa dalam diskusi kelompok maka siswa telah mengikuti proses pembelajaran menggunakan bahan ajar pergeseran kesetimbangan dengan baik. 
Tabel 6. Rekapitulasi Penilaian Aktivitas siswa dalam Diskusi Kelompok

\begin{tabular}{lcc}
\hline \multicolumn{1}{c}{ Aspek yang dinilai } & Kategori & Persentase (\%) \\
\hline Menganalisis data berupa tabel, skema, dan bacaan & Baik & 53,2 \\
Menjawab pertanyaan pada uji diri, pertanyaan, kegiatan, dan kotak & Baik & 42,6 \\
biru & Baik & 46,8 \\
Menemukan konsep yang diperoleh berdasarkan analisis. & Baik & 51,1 \\
Mengajukan pertanyaan antar siswa atau dengan guru & Baik & 46,8 \\
Mempresentasikan hasil diskusi kelompok & \\
\hline
\end{tabular}

Tabel 7. Rekapitulasi Penilaian Sikap siswa dalam Diskusi Kelompok

\begin{tabular}{lcc}
\hline Aspek yang dinilai & Kategori & Persentase (\%) \\
\hline Kedisiplinan & Baik & 68,1 \\
Tanggung Jawab & Baik & 40,4 \\
Toleransi & Baik & 51,1 \\
Kerjasama & Baik & 48,9 \\
Perhatian & Baik & 40,9 \\
\hline
\end{tabular}

2)

Deskripsi Efektivitas Bahan Ajar

a) Efektivitas Bahan Ajar Ditinjau dari Jumlah Lulus

Persentase jumlah kelulusan siswa setelah menggunakan bahan ajar merupakan salah satu pedoman efektivitas bahan ajar. Batas minimal kriteria kelulusan yang ditentukan oleh Guru Kimia SMA Negeri 4 Palangka Raya sebesar 70. Tabel 4.5 merupakan rekapitulasi jumlah siswa yang mencapai kriteria lulus pada pretes maupun postes.

Tabel 4.5 memaparkan bahwa rata-rata persentase siswa yang lulus mengalami peningkatan dari 8,5 menjadi 93,6\%. Nilai rata-rata hasil belajar siswa meningkat dari 36,60 menjadi 70,70. Mahmudi (2005) menjelaskan keefektivan didefinisikan sebagai hubungan antara output dengan tujuan, semakin besar kontribusi output terhadap pencapaian tujuan maka semakin efektif suatu program atau kegiatan. Berdasarkan persentase peningkatan kelulusan dan rata-rata hasil belajar maka Bahan Ajar pergeseran kesetimbangan dalam meningkatkan hasil belajar siswa.

Tabel 8. Persentase Lulus dan Nilai Rata-rata Pretes-Postes Ditinjau dari Peringkat

\begin{tabular}{ccccc}
\hline \multirow{2}{*}{ Peringkat* } & \multicolumn{2}{c}{ Persentase Lulus (\%)** } & \multicolumn{2}{c}{ Rata-rata** } \\
\cline { 2 - 5 } & Pretes & Postes & Pretes & Postes \\
\hline Bawah & 0,0 & 66,6 & 15,57 & 56,65 \\
Sedang & 0,0 & 96,9 & 37,67 & 73,04 \\
Atas & 50,0 & 100,0 & 38,10 & 72,60 \\
\hline
\end{tabular}

Keterangan:* Ditentukan berdasarkan mean dan standar deviasi nilai pretes dengan Rumus 3.1 dan 3.2 .

** Dihitung berdasarkan jumlah siswa tiap peringkat.

Tabel 4.8 menjelaskan persentase kelulusan dan nilai rata-rata pretes postes ditinjau dari peringkat. Peringkat bawah mengalamai kenaikan persentase jumlah lulus yaitu pretes $0,00 \%$ dan postes $66,6 \%$. Rata-rata hasil belajar juga mengalami peningkatan yaitu pretes 15,57 dan postes 56,65 . Persentase pretes peringkat sedang sebesar $0,00 \%$ sedangkan postes sebesar $96,6 \%$ diimbangi 
dengan rata-rata peningkatan hasil belajar yaitu pretes 37,67 dan postes 73,04. Peringkat atas juga mengalami peningkatan persentase kelulusan sebesar 50,0\% untuk pretes dan 100,0\% untuk postes. Skor persentase kelulusan. Hackathorn et al (2011) \& Maryatun (2015) mengungkapkan bahwa bahan ajar dikatakan efektif jika jumlah persentase minimal kelulusan minimal 75\%. Data pada Tabel 4.5 menunjukkan terjadi peningkatan persentase kelulusan yaitu 93,6\% dan melebihi rata-rata minimal. Dengan demikian, Bahan Ajar pergeseran kesetimbangan meningkatkan hasil belajar.

\section{b) Efektivitas Bahan Ajar Ditinjau dari $N$-gain score}

Analisis hasil pretes dan postes menggunakan $n$-gain score dapat melihat kefektivan bahan ajar. Tabel 4.9 adalah hasil rekapitulasi data Lampiran 18. Berdasarkan Tabel 4.9 persentase siswa yang memperoleh $n$-gain score kategori rendah 2,1\%; sedang 93,6\%; dan tinggi 4,3\%. Kategori n-gain score menggunakan kriteria yang diajukan oleh Hake (1998) yaitu tinggi jika lebih besar atau sama dengan 0,70; sedang jika antara 0,70 dan kurang dari atau sama dengan 0,30; dan rendah jika kurang dari 0,3. Rata-rata n-gain score dengan kategori sedang yaitu 0,54 . Oleh karena itu, bahan ajar efektif meningkatkan hasil belajar siswa pada materi unsur golongan 15 bila ditinjau dari $n$-gain score.

\section{Tabel 9. Persentase Kategori $\mathbf{N}$-gain Score Pretes-Postes}

\begin{tabular}{ccc}
\hline Persentase $(\%)$ & Kategori & $\boldsymbol{N}$-gain score $(\mathbf{g})^{*}$ \\
\hline 2,1 & Rendah & $<0,30$ \\
93,6 & Sedang & $0,70>\mathrm{g} \geq 0,30$ \\
4,3 & Tinggi & $\geq 0,70$ \\
Rata-rata Total & Sedang & $\mathbf{0 , 5 4}$ \\
\hline Keterangan: $*$ Interval kategori menggunakan kriteria menurut Hake (1998)
\end{tabular}

Keterangan: *Interval kategori menggunakan kriteria menurut Hake (1998)

$N$-gain score juga ditinjau dari peringkat siswa yang disajikan pada Tabel 4.10. Tabel 4.10 adalah rekapitulasi n-gain score siswa yang dianalisis berdasarkan peringkat bawah, sedang, dan tinggi. $N$-gain score memberi informasi peningkatan pada nilai pretes-postes. Bahan ajar dapat meningkatkan hasil belajar siswa pada setiap peringkat. Rata-rata $n$-gain score siswa peringkat bawah, sedang, dan atas berturut-turut yaitu 0,49; 0,56; dan 0,56. Selisih nilai tidak terlalu signifikan. Data menunjukkan bahwa peningkatan pretes-postes hampir sama pada setiap peringkat siswa setelah menggunakan bahan ajar. 
Tabel 10. $N$-gain Score Ditinjau dari Peringkat

\begin{tabular}{cccc}
\hline Peringkat & $\begin{array}{c}\text { Kategori } \\
\boldsymbol{N} \text {-gain Score }\end{array}$ & Persentase $(\%)^{*}$ & $\begin{array}{c}\text { Rata-rata } \\
\text { N-gain Score* }\end{array}$ \\
\hline \multirow{3}{*}{ Bawah } & Rendah & 0,0 & \\
& Sedang & 100 & 0,49 \\
& Tinggi & 0,0 & \\
\multirow{3}{*}{ Sedang } & Rendah & 3,03 & 0,56 \\
& Sedang & 93,9 & \\
& Tinggi & 3,03 & 0,56 \\
& Rendah & 0,0 & \\
& Sedang & 87,5 & $\mathbf{0 , 5 4}$ \\
\hline
\end{tabular}

Keterangan: *Dihitung berdasarkan jumlah siswa pada tiap peringkat.

\section{Kesimpulan}

Berdasarkan hasil penelitian dan analisis data yang dilakukan dapat disimpulkan bahwa :

1. Hasil Pengembangan melewati dua tahap uji kelayakan yaitu : (1) uji ahli dan (2) uji keterbacaan perorangan. Hasil uji kelayakan masing-masing memberikan penilaian bagi produk yang dikembangkan. Berdasarkan hasil uji coba kategori kelayakan produk adalah layak. Persentase penilaian uji ahli dan perorangan berturut-turut adalah 92,9\%.

2. Setelah melalui proses uji kelayakan, produk selanjutnya diukur efektivitas. Uji efektivitas bertujuan untuk mengetahui keefektifan produk yang dikembangkan dalam meningkatkan hasil belajar siswa. Instrumen tes yang dikembangkan telah melewati tahap validasi ahli dan uji coba. Pengembangan instrumen tes berorientasi pada sebaran indikator materi pergeseran kesetimbangan. Instrumen dapat digunakan untuk mengukur hasil belajar setelah menggunakan bahan ajar pergeseran kesetimbangan. Berdasarkan penelitian empiris pada siswa kelas XII digunakan sebagai buku penunjang kegiatan pembelajaran pada materi pergeseran kesetimbangan. Jumlah siswa yang dapat mencapai kriteria lulus meningkat dari 8,5 menjadi 93,6\%. Presentase kelulusan dari nilai $n$-gain score digunakan sebagai dasar untuk mengetahui efektivitas bahan ajar. Jumlah siswa yang lulus meningkatkan dari 8,5 menjadi 93,6\% dan nilai ratarata mengalami peningkatan dari 36,60 menjadi 72,70 . Capaian nilai $n$-gain score hasil belajar diperoleh kategori tinggi 96,9\%; kategori sedang 3,03\% dan kategori rendah 3,03\%. Rata-rata keseluruhan nilai n-gain score KGS diklasifikasikan sebagai kategori sedang yaitu 0,54. Oleh karena itu, berdasarkan tinjauan persentase jumlah lulus dan n-gain score maka Bahan Ajar pergeseran kesetimbangan efektif meningkatkan hasil belajar.

\section{Saran :}

Berdasarkan hasil penelitian, maka penulis mengajukan beberapa saran sebagai berikut : 
1. Diharapkan siswa sudah memahami konsep prasyarat dengan baik mengingat karakteristik materi yang tinggi.

2. LKS dapat dirancang lebih kreatif, lebih menjembatani pemahaman siswa sehingga memperoleh konsep dan menggunakan kata-kata yang sederhana sehingga mudah dipahami siswa.

\section{Daftar Pustaka}

Arifin, Mulyadi, DKK. 2000. Pengembangan Kurikulum dan Pembelajaran Kimia: Universitas Terbuka.

Dahar, R. W. 2011. Teori-teori Belajar dan Pembelajaran. Bandung. Penerbit Erlangga.

Istiyono, E., Supahar., Pujianto. 2007. Pembelajaran Kontekstual dalam Peningkatan Efektivitas Pembelajaran Analisis Rangkaian Listrik. Journal Cakrawala Pendidikan, 1(3): 281-293.

Nentwig, P.M., Demuth, R., Parchmann, I.,Grasel, C., \& Ralle, B. 2007. Chemie im Kontext: Situating Learning in Relevant Context while Systematically Developing Basic Chemical Concepts. Journal of Chemical Education, 9 (84): 1439-1444.

Suprihatiningrum, Jamil. 2014. Strategi Pembelajaran Teori \& Aplikasinya. Jogjakarta. Penerbit: Ar-Ruzz Media

Thiagarajan, S., Semmel, D.S., \& Semmel, M.I. 1974. Instructional Development for Training Teachers of Expectional Children. Minneapolis, Minnesota: Leadership Training Institute/Special Education, University of Minnesota. 